\title{
Comparative evaluation of fish assemblages census on an artificial reef
}

\author{
Daniel S. Brotto '; Werther Krohling ${ }^{1} \&$ llana R. Zalmon 1, 2 \\ 1 Universidade Estadual do Norte Fluminense. Avenida Alberto Lamego 2000, 28013-602 Campos, Rio de Janeiro, Brasil. \\ ${ }^{2}$ Corresponding author. E-mail: ilana@uenf.br
}

\begin{abstract}
One of the main issues regarding artificial reef fish evaluation is the performance of an efficient visual census sampling. An experimental artificial reef made of four different types of concrete modules was implanted on the north coast of Rio de Janeiro $\left(21^{\circ} 29^{\prime} \mathrm{S}, 41^{\circ} \mathrm{OOW}\right)$. Two interval-sampling periods using a visual census method were performed in the summer of $2003(\mathrm{~N}=6)$ and $2004(\mathrm{~N}=6)$, weekly and daily, respectively. The longer interval-sampling period showed twice of species with eight exclusive ones. Total fish abundance was higher during the shorter interval-sampling period, due to the presence of large shoals of Chloroscombrus chrysurus (Linnaeus, 1766) and Haemulon aurolineatum (Cuvier, 1829) especially at the complex modules. Fish abundance according to vertical position and feeding habits in the two interval sampling-periods showed a clear association to the structural complex modules, reinforcing the shelter influence on local fish assemblage structure and composition. The second survey showed quite different diversity and taxonomic results and highlighted the impossibility of obtaining several independent samples in a short period.of time.
\end{abstract}

KEY WORDS. Experimental reef complex; Rio de Janeiro; sampling period; underwater visual census.

RESUMO. Avaliação amostral comparativa da assembléia de peixes em um recife artificial. Uma das questões mais relevantes com relação à avaliação de peixes em recifes artificiais é a forma de se obter amostragens eficientes. Um recife artificial experimental foi construído a partir de diferentes tipos de módulos de concreto na costa norte do Rio de Janeiro $\left(21^{\circ} 29^{\prime} \mathrm{S}, 41^{\circ} \mathrm{OOW}\right)$. Dois períodos de intervalos de amostragem pelo método de censo visual foram realizados no verão de $2003(n=6)$ e de $2004(n=6)$, semanal e diário, respectivamente. $O$ período amostral mais espaçado apresentou o dobro de espécies, sendo oito exclusivas. $O$ número total de peixes foi mais elevado no intervalo de amostragem mais curto devido à presença de grandes cardumes de Chloroscombrus chrysurus (Linnaeus, 1766) e Haemulon aurolineatum (Cuvier, 1829), principalmente nos módulos complexos. A abundância de peixes de acordo com a posição vertical na coluna d'água e com os hábitos alimentares nos dois períodos investigados demonstrou uma associação aos módulos estruturalmente complexos, reforçando a influência do abrigo na composição e estrutura da assembléia de peixes no complexo recifal. $O$ segundo intervalo amostral investigado apresentou diferentes resultados taxonômicos, de abundância e diversidade e reforçou a impossibilidade de obtenção de várias amostras independentes em um curto período de tempo.

PALAVRAS-CHAVE. Censo visual subaquático; complexo recifal experimental; Rio de Janeiro.

Despite the considerable effort on artificial reef construction the knowledge of inherent ecological processes is not well known (Bohnsack \& Sutherland 1985, Grove \& Wilson 1994, SeAMAN 2000, FARIA et al. 2001, Gomes et al. 2001, SouZA et al. 2002, ZALMON 2002). Comparative studies of the modeling effect of different factors on reef fish communities need efficient experimental designs that could allow independent sampling.

Underwater visual census is the most common sampling method for evaluating the fish community in natural or artificial reefs, and several manuals on this method are available (SAmOILYS 1997, LABRosse 2002). Sampling by visual census consists of a diver recording the estimated number of each fish species in a specified area (e.g. transect, quadrat) over a fixed time (FERREIRA et al. 2001).

The possibility of obtaining several independent samples in a short period of time and the visualization in situ of the real fish association with the substrates are the most desirable advantages of this method (SEAMAN 2000). However, high visibility is necessary.

It is widely accepted that the visual census method commonly used in artificial reef evaluations provides accurate estimates of species distribution and abundance patterns (CHOU et al. 1991, BeEts \& Hixon 1994, CARR \& Hixon 1997); however very few comparative analyses of different methodological approaches have been undertaken to critically evaluate their relative effectiveness under field conditions (SALE 1997, WiLLIS 2001). This study aims to compare the reef fish assemblage structure on an artificial reef through two visual censuses of identical sample size both in summer, but with different interval-sampling periods. 


\section{MATERIAL AND METHODS}

In January 2002 an artificial reef complex was settled at nine meters depth, 3.0 miles from the north coast of Rio de Janeiro state $\left(21^{\circ} 29^{\prime} \mathrm{S}, 41^{\circ} 00^{\prime} \mathrm{W}\right)$ on a flat and homogeneous bottom (Fig. 1).

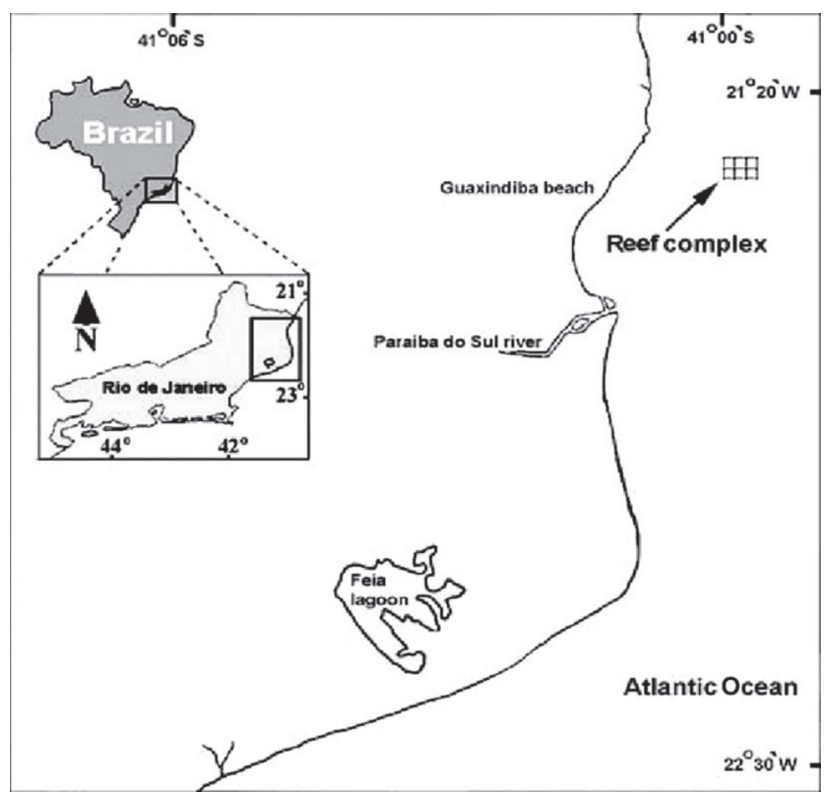

Figure 1. Artificial reef (AR) implantation site on north coast of Rio de Janeiro state.

The complex comprised 36 prefabricated reef balls of four types (Fig. 2) according to the combination of structural complexity ( $\mathrm{WC}=$ with complexity or $\mathrm{NC}=$ no complexity) and benthic recovery $(\mathrm{WB}=$ with benthic community or $\mathrm{NB}=$ no benthic community).

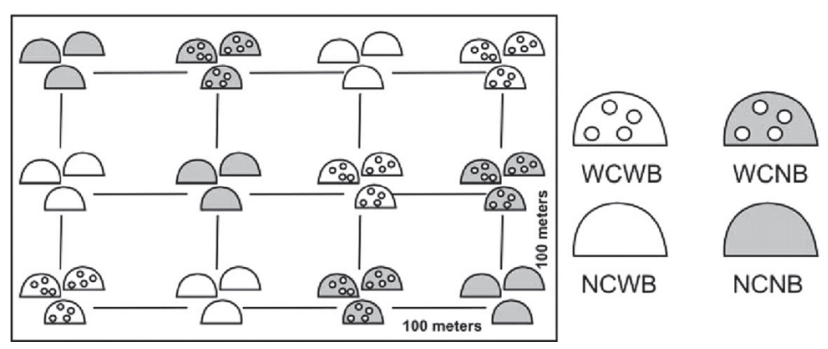

Figure 2. Spatial distribution of the different module types. (WCWB) Complex/with benthos, (WCNB) complex/non benthos, (NCWB) non complex/with benthos, (NCNB) non complex/non benthos, $\mathrm{N}=3$ in each module type.

Structural complexity was obtained by the presence or absence of holes/cavities and a favorable or unfavorable benthic surface by use of an anti-fouling paint (Tritão Cooperkote Akzo Nobel Coatings).

A sampling program using a stationary visual census method (BOHNSACK \& BANNEROT 1986) was performed weekly in February and March 2003 ( $\mathrm{N}=3 /$ month) and one year later using an interval-sampling period of one week, in March $2004(\mathrm{~N}=$ $6 /$ month) to determine the species composition, richness and abundance of reef fishes in each module type. The technique consists of a fish point count in a $6 \mathrm{~m}$-diameter cylinder, extending from the bottom to six meters high (Fig. 3). The visual census technique is commonly indicated for fish community evaluation at natural and artificial reefs (SAle \& Douglas 1981, SAmoIlys \& Carlos 2000, Seaman 2000, Brotto et al. 2006a,b, Floeter et al. 2007).

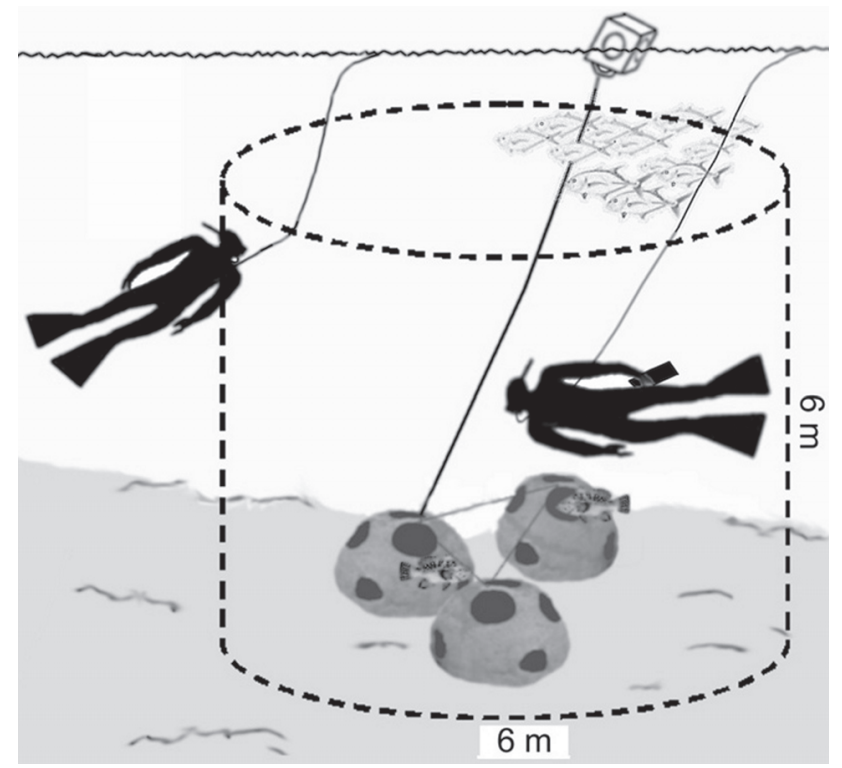

Figure 3. Schematic representation of the sampling method.

On each sampling date, trained divers (Brotto and Krohling) recorded at each of the twelve modules and the adjacent bottom all demersal, pelagic and benthic fishes seen during a five-minute period. Each sampling period encompassed a total of six hours (5 minutes x 12 modules x 6 sample dates) of visual census. Total length of each individual was estimated by comparing the size of the fish to the dimensions of a known object (rope, diving gear or reef modules).

Numerical descriptors of density, species richness and Shannon's diversity (ZAR 1984) and fish abundance according to vertical position and feeding habits (Figueiredo \& Menezes 1978a,b, Menezes \& Figueiredo 1980, 1985, Cervigon et al. 1993) were used to determine differences in fish structure assemblages according to each module type and interval-sampling period. A cluster analysis (UPGMA, Euclidean distance similarity index) was performed to determine the similarity between fish assemblages of both interval-sampling periods considering total abundance of each species on each sampling date. 
Comparative analysis of species richness and abundance values between interval-sampling periods and module types was carried out by ANOVA using all six sample units $(\mathrm{p}<0.05)$ followed by an a posteriori Tukey test (HSD). Richness and abundance values were log-transformed to minimize heterocedasticity.

\section{RESULTS}

In the present study it was possible to compare different interval-sampling periods (weekly versus daily) using the same method (visual census), sample size $(\mathrm{N}=6)$ and season of the year (summer 2003 and summer 2004).

In 2003 sampling period 4542 fish (21 species) were registered, while in 2004 a total of 8855 fish (11 species) were observed. A total of eight species were only observed in the summer of 2003 and 11 species were common to both periods (Tab. I).

Total fish number did not present significant differences between both interval-sampling periods, although in the first one significantly $(\mathrm{p}=0.00)$ higher values were found at complex modules and also in summer 2004, but at the non-complex ones (Fig. 4). Species richness and diversity showed significantly higher values ( $\mathrm{p}=0.00$ and $\mathrm{p}=0.01$, respectively) in 2003 at the complex modules (Fig. 4).

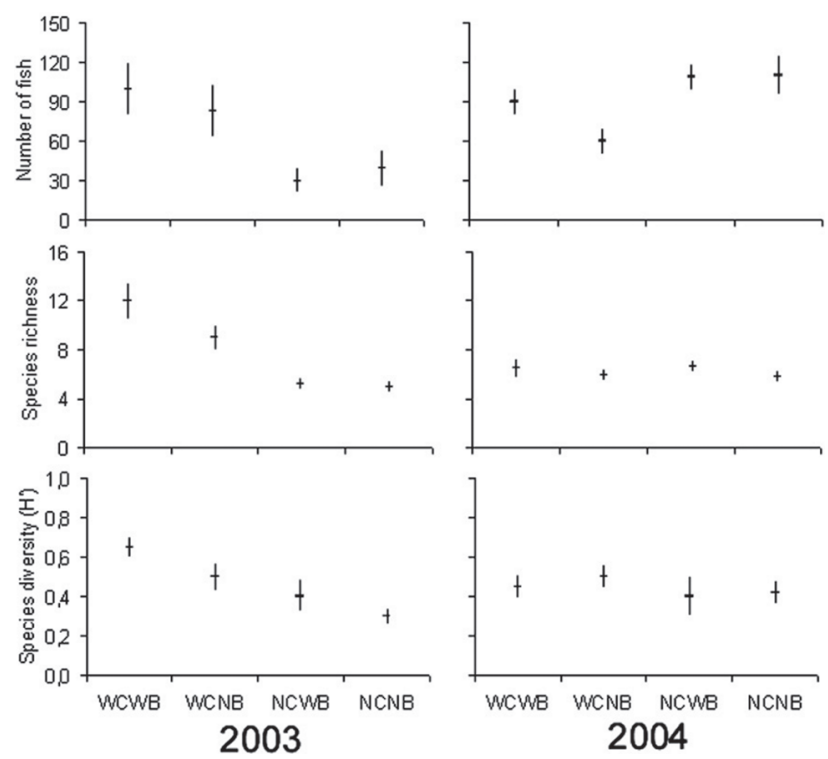

Figure 4. Number of individuals, species richness and diversity (mean values \pm standard deviation) in four module types on 2003 and 2004 interval-sampling periods ( $N=6$ in each). (WCWB) Complex with benthos, (WCNB) complex with non benthos, (NCWB) non complex with benthos, (NCNB) non complex with non benthos.

In the 2003 sampling period functional groups of benthic, demersal, generalist, invertivorous, omnivorous and predator fishes (according to Figueiredo \& Menezes 1978a,b, Menezes \& Figueiredo 1980, 1985, Cervigon et al. 1993) showed significant differences among module types with a clear association pattern of these fishes to the complex ones. In the 2004 sampling period these functional groups did not present any pattern among the different modules (Tab. II).

The abundance of the dominant species showed significant differences between interval-sampling periods (Tab. III). Haemulon aurolineatum (Cuvier, 1829), Serranus flaviventris (Cuvier, 1829), Caranx latus (Agassiz, 1831) and Chloroscombrus chrysurus (Linnaeus, 1766) were more abundant in the 2004 sampling period, while Chaetodipterus faber (Broussonet, 1782) predominated in 2003. Significant variations between modules were observed for $S$. flaviventris and $C$. latus abundances, with both species presenting lower densities at the non-complex ones.

A clear difference in the fish assemblages of both interval-sampling periods was revealed by cluster analysis (Fig. 5), with all the six sampling dates of each period together in a single group.

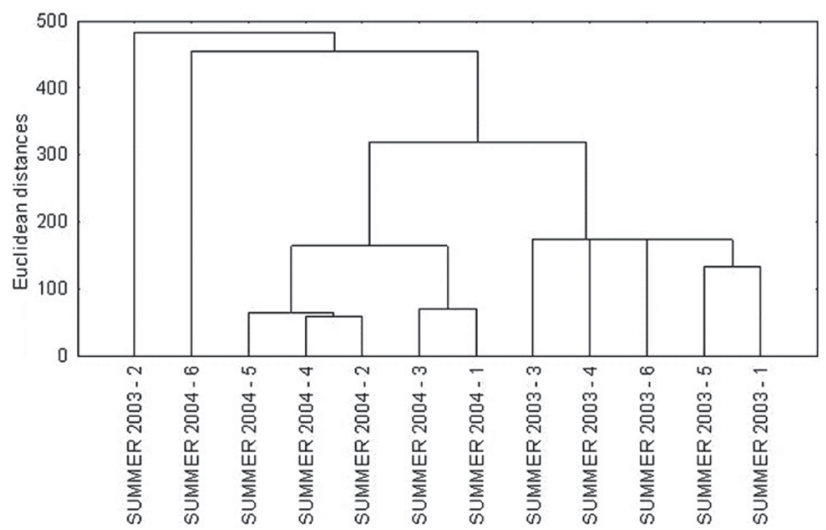

Figure 5. Cluster analysis (UPGMA, Euclidean distance) of fish assemblages on each sample date of both sampling periods summer 2003 and summer 2004.

\section{DISCUSSION}

Total fish abundance was higher during the shorter interval-sampling period, due to the presence of large shoals of $C$. chrysurus and $H$. aurolineatum especially at the complex modules, which offer shelter. BoHNSACK \& BANNEROT (1986) state that the presence of highly mobile schooling species is a chance occurrence. The spatial distribution pattern in this sampling period as well as higher fish abundances could be related to internal waves produced by the strong local currents (sensu KIMURA 1987). This might be compelling the schooling fishes to remain closer to the modules. This assumption is reinforced by Samoilys \& Carlos (2000), who suggest that fish mobility and search efficiency are key factors in optimizing underwater visual census method.

The highest species richness, diversity and number of exclusive species were registered in the 2003 sampling period. With a longer interval-sampling period it was possible to infer 
Table I. Total number of each fish species on 2003 and 2004 sampling periods and their correspondent functional groups - (Inv) Invertivorous, (Omn) omnivorous, (Herb) herbivorous, (Pred) predator, (Benth) benthic, (Dem) demersal, (Pel) pelagic, (Hard) hard bottom, (Gen) bottom generalist - according to Cervigon et al. (1993), Figueiredo \& Menezes (1978a, b), Menezes \& Figueiredo (1980, 1985).

\begin{tabular}{|c|c|c|c|}
\hline Species & Functional groups & 2003 & 2004 \\
\hline Haemulon steindachneri (Jordan \& Gilbert, 1882) & Inv/dem/gen & 1596 & 0 \\
\hline Chaetodipterus faber (Broussonet, 1782) & Inv/dem/gen & 1041 & 81 \\
\hline Chloroscombrus chrysurus (Linnaeus, 1766) & Inv/pel/gen & 946 & 5332 \\
\hline Serranus flaviventris (Cuvier, 1829) & Pred/benth/hard & 203 & 642 \\
\hline Orthopristis ruber (Cuvier, 1830) & Pred/dem/gen & 149 & 0 \\
\hline Halichoeres poey (Steindachner, 1867) & Pred/dem/hard & 135 & 143 \\
\hline Haemulon aurolineatum (Cuvier, 1829) & Inv/dem/hard & 115 & 1909 \\
\hline Caranx latus (Agassiz, 1831) & Pred/pel/gen & 113 & 441 \\
\hline Lutjanus analis (Cuvier, 1828) & Pred/dem/hard & 44 & 0 \\
\hline Mycteroperca microleps (Goode \& Bean, 1880) & Pred/dem/hard & 42 & 0 \\
\hline Equetus acuminatus (Bloch \& Schneider, 1801) & Inv/dem/hard & 36 & 51 \\
\hline Acanthurus bahianus (Castelnau, 1855) & Herb/dem/hard & 30 & 87 \\
\hline Chaetodon striatus (Linnaeus, 1758) & Inv/dem/hard & 18 & 43 \\
\hline Mycteroperca acutirostris (Bloch, 1793) & Pred/dem/hard & 17 & 55 \\
\hline Holocentrus adcenscionis (Osbeck, 1765) & Inv/dem/hard & 17 & 0 \\
\hline Scorpaena isthimensis (Meek \& Hildebrand, 1928) & Pred/benth/hard & 13 & 71 \\
\hline Gymnothorax funebris (Ranzani, 1840) & Pred/benth/hard & 8 & 0 \\
\hline Serranus auriga (Cuvier, 1829) & Pred/benth/hard & 7 & 0 \\
\hline Cyclichthys spinosus (Cuvier, 1818) & Inv/dem/hard & 5 & 0 \\
\hline Archosargus romboidalis (Linnaeus, 1758) & Omn/dem/hard & 4 & 0 \\
\hline Acantostracium quadricornis (Linnaeus, 1758) & Omn/dem/hard & 3 & 0 \\
\hline Total & & 4542 & 8855 \\
\hline
\end{tabular}

Table II. ANOVA and a posteriori Tukey test of total number of fish according to functional groups between module types in each sampling period: (WCWB) complex with benthos, (WCNB) complex with non benthos, (NCWB) non complex with benthos, (NCNB) non complex with non benthos.

\begin{tabular}{lll}
\hline \multicolumn{1}{c}{ Functional groups } & \multicolumn{2}{c}{ Sampling periods } \\
\cline { 2 - 3 } Benthic & NCWB and NCNB $<$ WCWB and WCNB & WCWB and NCWB $<$ WCNB and NCNB \\
Demersal & NCWB and NCNB $<$ WCWB and WCNB & $\mathrm{ns}$ \\
Pelagic & $\mathrm{ns}$ & WCWB and WCNB $<$ NCWB and NCNB \\
Hard bottom & WCNB, NCWB and NCNB $<$ WCWB & $\mathrm{ns}$ \\
Soft bottom & $\mathrm{ns}$ & - \\
Generalist & $\mathrm{NCWB}$ and NCNB $<$ WCWB and WCNB & WCWB and NCNB $<$ WCNB and NCWB \\
Invertivorous & $\mathrm{NCWB}$ and NCNB $<$ WCWB and WCNB & WCWB and WCNB $<$ NCWB and NCNB \\
Omnivorous & $\mathrm{NCWB}$ and NCNB $<$ WCWB and WCNB & - \\
Herbivorous & $\mathrm{ns}$ & WCWB and WCNB $<$ NCWB and NCNB \\
Predator & $\mathrm{NCWB}$ and NCNB $<$ WCWB and WCNB & WCNB and NCWB $<$ WCWB and NCNB \\
\hline
\end{tabular}

(ns) Non significant $(p<0.05)$, (-) absent.

the importance of the functional role of structural substrate complexity as a modeling agent of reef fish assemblage, which was reflected by different fish association patterns to the complex and non-complex modules.
Fish abundance according to vertical position and feeding habits in the two interval-sampling periods showed the same distribution pattern according to module type, reinforcing the shelter influence on local fish assemblage structure and 
Table III. Anova of the most abundant fish species and Tukey test a posteriori between sampling periods (2003 and 2004) and module types.

\begin{tabular}{llrll}
\hline \multicolumn{1}{c}{ Species } & Comparison & $\mathrm{F}$ & $\mathrm{p}$ & \multicolumn{1}{c}{ Significant differences } \\
\hline H. aurolineatum & between periods & 5.16 & 0.024 & $2003<2004$ \\
& between modules & 1.73 & 0.162 & $\mathrm{~ns}$ \\
S. flaviventris & between periods & 61.36 & 0.000 & $2003<2004$ \\
& between modules & 5.57 & 0.001 & $\mathrm{NCWB}, \mathrm{NCNB}<\mathrm{WCWB}, \mathrm{WCNB}$ \\
C. faber & between periods & 30.94 & 0.000 & $2003>2004$ \\
& between modules & 1.25 & 0.292 & $\mathrm{~ns}$ \\
C. latus & between periods & 10.71 & 0.013 & $2003<2004$ \\
& between modules & 3.39 & 0.019 & $\mathrm{NCWB}<\mathrm{NCNB}, \mathrm{WCWB}, \mathrm{WCNB}$ \\
C. chrysurus & between periods & 64.16 & 0.000 & $2003<2004$ \\
& between modules & 1.75 & 0.157 & $\mathrm{~ns}$
\end{tabular}

(ns) Non significant $(p<0.05)$.

composition. Also, Charbonnel et al. (2002), SHERman et al. (2002) and KAWASAKI et al. (2003) related higher fish density and richness to habitats with higher structural complexity in artificial reef environments.

As reef environments present patchy fish distribution, a large amount of data is required to reduce variance and distinguish trends (Pattengill-Semmens \& Sammarco 1998). Goodall (1970) suggested that increasing sampling effort is the most effective way to increase accuracy in data collection. However, a more intensive sampling program performed over a short period of time (one week) had quite different results compared to those obtained by the same method over a longer intervalsampling period (two months). The ability to make accurate estimative of fish densities is the basis of both ecological and environmental studies, and inconsistent sampling methods might produce misleading results even in otherwise well-designed surveys (Wilus et al. 2000).

It is well known that sample design might affect the consistency of data and could lead to incorrect interpretation of observed patterns. This study revealed that a short time interval between sampling dates for artificial reef fish assemblages characterization by underwater visual census might not reflect the real community structure and their modeling agents. A longer visual interval-sampling period showed a more accurate result, which must be considered when studying the habitat's influence on reef fish community structure.

\section{ACKNOWLEDGEMENTS}

We would like to thank CNPq (Process 302303/2002-2, 470093/2003-0) and FAPERJ (Process E26/171-446/2000, E26/ 171-313/2004) for the financial support and scholarships.

\section{REFERENCES}

Beets, J. \& M.A. Hixon. 1994. Distribution, persistence, and growth of groupers (Pisces: Serranidae) on artificial and natural patch reefs in the Virgin Islands. Bulletin of Marine
Science 50: 470-483.

BohnsaCK, J.A. \& D.L. SutherLand. 1985. Artificial reef research: A review with recommendations for future priorities. Bulletin of Marine Science 3: 11-39.

BOHNSACK, J.A. \& S.P. BANNEROT. 1986. A stationary visual census technique for quantitatively assessing community structure of coral reef fishes. Seattle, NOAA Technical Report NMFS 41, 15p.

Brotto, D.S.; W. Krohling \& I.R. ZaLmon. 2006a. Usage patterns of an artificial reef by the fish community on the northern coast of Rio de Janeiro - Brazil. Journal of Coastal Research 39: 20-30.

Brotto, D.S.; W. Krohling \& I.R. ZaLmon. 2006b. Fish community modeling agents on an artificial reef on the northern coast off Rio de Janeiro - Brazil. Brazilian Journal of Oceanography 54 (4): 205-212

Carr, M.H. \& M.A. Hixon. 1997. Artificial Reefs: The importance of comparisons with natural reefs. Fisheries 22: 28-33.

Cervigon, F.; R. Cipriani; W. Fischer; L. Garibaldi; M. Hendrickx; A.J. Lemus; R. Marquez; J.M. Poutiers; G. Robaina \& B. RoDRIGUEz. 1993. Field guide to the commercial marine and brackish water resources of the northern coast of South America. FAO species identification sheets for fishery purposes. Rome, Food and Agriculture Organization of the United Nations, 350p.

Charbonnel, E.; C. Serre; S. Ruitton; J.G. Harmelin \& A.C. Jensen. 2002. Effects of increased habitat complexity on fish assemblages associated with large artificial reef units (French Mediterranean coast). ICES Journal of Marine Science 59: 208-213.

Chou, L.M.; G.S.Y. Lim \& C.B. Leng. 1991. An assessment of fish communities of artificial reef structures in Brunei Darussalam with recommendations for management and development. Research and Management Optimization 1 (9) 15-31.

Faria, V.V.; M.P. Gomes; R. Novelli \& I.R. Zalmon. 2001. Potencial atrator de peixes cartilaginosos em recife artificial no litoral norte do Estado do Rio de Janeiro. Revista Brasileira 
de Zoologia 18 (3): 779-792.

Ferreira, C.E.L.; J.E.A. GonÇAlves \& R. Coutinho. 2001. Community structure of fishes and habitat complexity in a tropical rocky shore. Environmental Biology of Fish 61: 353-369.

Figueiredo, J.L. \& N.A. Menezes. 1978a. Manual de peixes marinhos do sudeste do Brasil. II. Teleostei (1). São Paulo, Museu de Zoologia, Universidade de São Paulo, 110p.

Figueiredo, J.L. \& N.A. Menezes. 1978b. Manual de peixes marinhos do sudeste do Brasil. III. Teleostei (2). São Paulo, Museu de Zoologia, Universidade de São Paulo, 90p.

Floeter, S.R.; J.L. Gasparini; W. Krohling; C.E.L. \& I.R. Zalmon. 2007. Reef fish community structure on coastal islands of the southeastern Brazil: the influence of exposure and benthic cover. Environmental Biology of Fishes 78: 147-160.

Gomes, M.P.; V.V Faria; R. Novelli \& I.R. Zalmon. 2001. Potencial atrator de peixes ósseos em recife artificial no litoral norte do Estado do Rio de Janeiro. Revista Brasileira de Zoologia 18 (3): 813-821.

Goodall, D.W. 1970. Statistical plant ecology. Annual Review of Ecology and Systematics 1: 99-124.

Grove, R.S. \& C.A. Wilson. 1994. Introduction (Fifth International Conference on Aquatic Habitat Enhancement). Bulletin of Marine Science 55 (2-3): 265-267.

Kawasaki, H.; M. Sano \& T. Shibuno. 2003. The relationship between habitat physical complexity and recruitment of the coral reef damselfish, Pomacentrus amboinensis: an experimental study using small-scale artificial reefs. Ichthyological Research 50: 73-77.

KImURA, H. 1987. Artificial reef fish. Kochi, Fisheries Engineering Laboratory, Faculty of agriculture-Kochi University, 28p.

Labrosse, P. 2002. Underwater visual fish census surveys: proper use and implementation. Noumea, Secretariat of the Pacific Community, 60p.

Menezes, N.A. \& J.L. Figueiredo. 1980. Manual de peixes marinhos do sudeste do Brasil. IV. Teleostei (3). São Paulo, Museu de Zoologia, Universidade São Paulo, 96p.

Menezes, N.A. \& J.L. Figueiredo. 1985. Manual de peixes marinhos do sudeste do Brasil. V. Teleostei (4). São Paulo, Museu de Zoologia, Universidade de São Paulo, 105p.

Pattengill-Semmens, C.V. \& P.W. Sammarco. 1998. An analysis of fish survey data generated by non-experts in the Flower Garden Banks National Marine Sanctuary. Journal of Gulf of Mexico Science 16 (2): 196-207.

SALE, P.F. 1997. Visual census of fish: How well do we see what is there?, p. 1435-1440. In: H.A. Lessios \& I.G. MacInTyRe (Eds). Proceedings of the $8^{\text {th }}$ International Coral Reef Symposium 2. Balboa, Smithsonian Tropical Research Institute, 2119p. [ISBN: 0935868-89-5]

Sale, P.F. \& W.A. Douglas. 1981. Precision and accuracy of visual census technique for fish assemblages on coral patch reefs. Environmental Biology of Fishes 6: 333-339.

SAMOILYS, M.A. 1997. Manual for assessing fish stocks on Pacific coral reefs. Brisbane, The State of Queensland Department of Primary Industries, 75p.

Samoilys, M.A. \& G. Carlos. 2000. Determining Methods of Underwater Visual Census for Estimating the Abundance of Coral Reef Fishes. Environmental Biology of Fishes 57: 289304.

Seaman, W. 2000. Artificial reef evaluation with application to natural marine habitats. Boca Raton, CRC Press, 247p.

Sherman, R.L.; D.S. Gillian \& R.E. Spieler. 2002. Artificial reef design: void space, complexity, and attractants. ICES Journal of Marine Science 59: 196-200.

SouZA, E.G.A.; T.C. Almeida \& I.R. Zalmon. 2002. Fish assemblages and environmental variables on an artificial reef - Rio de Janeiro, Brazil. ICES Journal of Marine Science 59: 138143.

WiLLIS, T.J. 2001. Visual census methods underestimate density and diversity of cryptic reel fishes. Journal of Fish Biology 59: 1408-1411.

Willis, T.J.; R.B. Millar \& R.C. BABCOCK. 2000. Detection of spatial variability in relative density of fishes: comparison of visual census, angling, and baited underwater video. Marine Ecology Progress Series 198: 249-260.

Zalmon, I.R.; R. Novelli; M.P. Gomes \& V.V. Faria. 2002. Experimental results of an artificial reef program on the brazilian coast north of Rio de Janeiro. ICES Journal of Marine Science 59: 83-87.

ZAR, J.H. 1984. Biostatistical analysis. Englewood Cliffs, Prentice-Hall, $2^{\text {nd }}$ ed. $718 p$.

Received in 31.I.2007; accepted in 02.XII.2007. 